\title{
Over beperkte rationaliteit en strategische besluitvorming
}

\author{
Dr. G.W.I. Hendrikse
}

\section{Inleiding}

In de economische wetenschap zijn basisconcepten als vraag en aanbod en opportuniteitskosten in combinatie met het marginale en systeemdenken succesvol toegepast op een veelheid van problemen. In de theorievorming wordt beslissers meestal een perfecte, logische, deductieve rationaliteit toegeschreven. Deze deductieve benadering van rationaliteit wordt letterlijk opgevat. De kracht en het succes van deze gedragsveronderstelling ligt in het leit dat vele gebeurtenissen kunnen worden verklaard door te veronderstellen dat individuen zich gedragen 'as if' onbeperkte cognitieve capaciteiten aan hun keuzen ten grondslag liggen (Friedman, 1953). Vrijwel alle economen zijn het erover eens dat deze karakterisering van mensen niet realistisch is, maar men blijft er mee werken omdat er geen goed alternatief aanwezig is.

Het bovenstaande houdt in dat er andere besluitvormingsprocessen aan het gedrag van mensen ten grondslag liggen die dezelfde uitkomst met zich meebrengen als gedrag van volledig rationele beslissers. Een kanonskogel bezit zeker niet de intellectuele capaciteiten om een differentiaalvergelijking op te lossen, maar haar gedrag (baan) kan precies door een dergelijke vergelijking worden beschreven. De veronderstelling van volledige rationaliteit is dan geen probleem.

Dr. G.W.J. Hendrikse is als universitair hoofddocent verbonden aan de Katholieke Universiteit Brabant. Een gedeelte van dit onderzoek is uitgevoerd tijdens een verblijf aan het Center for Research in Management van de University of California te Berkeley.
Hetzelfde geldt voor de kritiek van Hayek ( 1945 ) op de veronderstelling van gecentraliseerde prijsvorming in het algemeen evenwichtsmodel van Arrow en Debreu (1959). Individuen verzamelen weliswaar lokatal informatie en komen lokaal tot prijsovereenstemming, maar dit is geen probleem zolang het 'onzichtbare hand' resultaat snel tol stand komt. Een dergelijke spanning tussen modelingrediënten en realiteitsgehalte geldt overigens ook voor modellen met andere gedragsveronderstellingen. Het 'garbage can' model van de onderneming (Cohen, March en Olsen, 1972) is gebaseerd op ambigue, inconsistente en vage besluitvormingsprocessen. Dit is geen probleem zolang het model goed voorspelt, ondanks dat betrokkenen het beschrijvingsgehalte vaak niet hoog achten. Het blijkt statistisch gezien bijzonder moeilijk om een onderbouwing van Gibrats wet, dat wil zeggen de lognormale verdeling van de omvang van ondernemingen in bedrijfstakken, louter op basis van een stochastisch proces te verwerpen (Simon en Bonini. 1958), ondanks het beschikbaar zijn van 'meer realistische' economische theorieën op dit gebied. Deze modellen worden echter problematisch wanneer individuen beslissingen nemen die systematisch van de modelvoorspellingen afwijken.

Er zijn al vele pogingen ondernomen om op de een of andere manier beperkte rationaliteit in modellen te verwerken. Dit kan expliciet gebeuren of men kan het omzeilen via de specificatie van een parameter. Een voorbeeld van het eerste is de literatuur over finite automata (Kalai, 1990), terwij! het ad-hoc specificeren van fouten (Sah en Stiglitz, 1986), onvolledige contracten (Williamson, 1979) of tijdsduur van beslissingen (Radner, 1992) aan het begin van een analyse voorbeelden zijn van de tweede werkwijze. 
Er zijn vele manieren om beperkte rationaliteit te definiëren en elke definitie zal daardoor enigszins ad hoc zijn. Er is namelijk maar één manier om volledig rationeel te zijn, terwijl er vele mogelijkheden zijn om beperkt rationeel te zijn. De te bespreken expliciete operationaliseringen van beperkte rationaliteit zijn dan ook tot op zekere hoogte willekeurig. Er wordt toch bij enkele recente ontwikkelingen op het gebied van beperkte rationaliteit stilgestaan omdat zij de potentie lijken te hebben voor veel vruchtbaar onderzoek. Het oogmerk van dit artikel is om hiertoe aanzetten te formuleren. De nadruk zal liggen op management en organisatie, omdat er in dit vakgebied weinig theorievorming is die de rijkdom aan empirische observaties enigszins organiseert.

Paragraaf 2 staat stil bij deductieve beperkte rationaliteit en formuleert toepassingen met betrekking tot diversificatie en prijsdiscriminatie. Paragraaf 3 beschrijft enkele ontwikkelingen ten aanzien van inductieve beperkte rationaliteit en illustreert de gepresenteerde ideeën met toepassingen op het gebied van segregatie en financiële markten. Paragraaf 4 vat een aantal empirische bevindingen op het gebied van de strategische besluitvorming samen die moeilijk zijn te rijmen met de standaard economische theorie. De suggestie is dat de ideeën uit de paragrafen 2 en 3 een vruchtbaar startpunt kunnen vormen voor een theoretische onderbouwing van deze observaties. Paragraaf 5 besluit het artikel met een conclusie.

\section{Deductieve beperkte rationaliteit}

De mate van rationaliteit kan worden gedefinieerd als het verschil tussen de cognitieve capaciteiten van een beslisser en de complexiteit van het probleem (Heiner, 1983). Dit verschil is gelijk aan nul wanneer er sprake is van volledige rationaliteit, dat wil zeggen dat de cognitieve capaciteiten van de beslisser toereikend zijn om alle relevante aspecten van het onderhavige probleem te duiden. Beperkte rationaliteit houdt in dat de cognitieve capaciteiten kleiner zijn dan de complexiteit van het probleem. Beroemd is in deze context de karakterisering van beperkte rationaliteit met de zinsnede '... intendedly rational, but only limitedly so' door Simon (1961), Tenslotte, procedurele rationaliteit houdt in dat dit verschil groot is. Het probleem is voor de beslisser veel te complex om het te kunnen doorgronden. Merk op dat het verschil kan worden verminderd door ofwel de cognitieve capaciteiten te vergroten (door het volgen van onderwijs) ofwel de complexiteit van het probleem te verkleinen (door het inschakelen van hulpmiddelen zoals de computer).

De mate van rationaliteit is nu weliswaar gedefinieerd, maar er is nog geen operationele invulling gegeven aan het niveau van de cognitieve capaciteiten en het niveau van complexiteit. Een manier om dit vorm te geven is de mate van opsplitsing (partitionering) van de verzameling van mogelijke gebeurtenissen (toestanden) als maatstaf te gebruiken. Het probleem van kleurkenning zal als toelichting worden uitgewerkt. Neem aan dat er vier mogelijke toestanden zijn: $\mathrm{R}$ (ood), G(roen), W(it) en A(ndere toestanden van andere dimensies als zuurstofgehalte, materiaalsamenstelling, esthetiek en emotionaliteit). De complexiteit van dit probleem is drie, omdat de meest fijne opsplitsing van de verzameling toestanden wordt bereikt na drie stappen. Dit kan als volgt worden ingezien. Eerst splitst men de verzameling toestanden in Rood en niet-Rood, vervolgens splitst men de verzameling niet-Rood in Groen en niet-Groen en ten slotte wordt de verzameling niet-Groen gesplitst in Wit en nietWit, dat wil zeggen Andere toestanden. Een andere manier om drie 'streepjes te trekken' is om de verzameling toestanden eerst te splitsen in enerzijds Rood en Groen en anderzijds Wit en Andere. Vervolgens wordt de verzameling (R,G) gesplitst in $(R)$ en $(G)$ en ten slotte $(W, A)$ in $(W)$ en (A).

Het niveau van de cognitieve capaciteiten hangt af van de aard van de beslisser. Neem aan dat er vier beslissers zijn: mens, poes, mol en soeplepel. De mens is in dit probleem van kleurherkenning in staat om alle toestanden van elkaar te onderscheiden. Het niveau van de cognitieve capaciteiten van de mens is derhalve 3 . Een poes is niet in staat om de kleuren Rood en Groen van elkaar te onderscheiden. Zij is niet in staat om de verzameling (R.G) te partitioneren in de verzamelingen $(R)$ en $(G)$. De kleur Wit wordt herkend, evenals de toestand waarin er geen sprake is van één van de drie kleuren. De poes is in staat om twee streepjes te trekken in de verzameling toestanden, waardoor het niveau van de cognitieve capaciteiten van de poes gelijk is aan 2. Een mol is slechts in staat om licht van geen licht te onderscheiden, dat wil zeggen dat de verzameling (R,G.W) niet kan worden opgesplitst. Het niveau 
van de cognitieve capaciteiten van de mol is één, omdat de verzameling toestanden slechts opgesplitst kan worden in (R,G,W) en (A). Ten slotte, het niveau van de cognitieve capaciteiten van de soeplepel is nul omdat geen van de toestanden van elkaar kan worden onderscheiden. Tabel 1 vat het kleurherkenningsprobleem samen.

Tabel 1: Kleurherkenningscapaciteiten van verschillende beslissers

\begin{tabular}{lrr}
\hline Beslisser & $\begin{array}{r}\text { Partitie verzameling } \\
\text { toestanden }\end{array}$ & $\begin{array}{r}\text { Cognitieve } \\
\text { capaciteiten }\end{array}$ \\
Mens & $\{(\mathrm{R}),(\mathrm{G}),(\mathrm{W}),(\mathrm{A})\}$ & 3 \\
Poes & $\{(\mathrm{R}, \mathrm{G}),(\mathrm{W}),(\mathrm{A})\}$ & 2 \\
Mol & $\{(\mathrm{R}, \mathrm{G}, \mathrm{W}),(\mathrm{A})\}$ & 1 \\
Soeplepel & $\{(\mathrm{R}, \mathrm{G}, \mathrm{W}, \mathrm{A})\}$ & 0 \\
\hline
\end{tabular}

Merk op dat er hier sprake is van deductieve beperkte rationaliteit. Het probleem wordt eerst wiskundig precies weergegeven, waarna de beslissers vervolgens worden verondersteld om hun beperkte cognitieve capaciteiten optimaal toe te wijzen in het onderhavige probleem. Met de diversificatie en prijsdiscriminatietoepassingen zal worden aangetoond dat deze operationalisering van beperkte rationaliteit met succes kan worden toegepast. Daarnaast zal duidelijk worden dat het incorporeren van beperkte rationaliteit in economische theorieën niet op gespannen voet staat met de neo-klassieke werkwijze.

\section{I Diversificatie}

Managers voeren verschillende taken uit, zoals het beoordelen en formuleren van investeringsprojecten, het evalueren van marktont wikkelingen en het bepalen van de strategie van de onderneming. Beperkte cognitieve capaciteiten zullen in deze beleidsbeslissingen tot uiting komen.

Fershtman en Kalai (1993) analyseren de relatie tussen de diversificatiegraad van de onderneming en de intensiteit van de concurrentie in de verschillende markten. De complexiteit van het probleem van de beperkt rationele manager wordt bepaald door het aantal markten waarin de onderneming actief is en het aantal concurrenten dat in elke markt opereert. Het optimale aantal markten is beperkt omdat elke nieuwe markt minstens een eenheid cognitieve capaciteiten vergt. Dit gaat ten koste van een markt waarin men al actief is, waardoor er twee extra markten zijn in de nieuwe portfolio van markten waaraan nog slechts oppervlakkig kennis wordt besteed.

Naarmate meer aandacht wordt besteed aan specifieke marktomstandigheden zal het reageren op strategische zetten van rivalen minder aandacht kunnen krijgen van de manager. Dit kan leiden tot het afstoten van markten waarin er toetreding plaatsvindt. Het is ook mogelijk dat beperkte cognitieve capaciteiten tot minder toetreding zullen leiden dan de situatie waarin de manager beschikt over volledige rationaliteit. Coöperatie met een toetreder vergt meer van de cognitieve capaciteiten dan een niet-coöperatieve strategie. De beperkte rationaliteit van de gevestigde onderneming kan ertoe leiden dat toetreding wordt verhinderd, omdat het meer eenvoudige nietcoöperatieve scenario toetreding minder aantrekkelijk maakt.

\subsection{Prijscatalogus}

Consumenten verschillen in de standaard economische theorie omdat ze niet dezelfde voorkeuren hebben of verschillende informatie tot hun beschikking hebben. In de praktijk is er ook sprake van verschillende intelligentieniveaus, hetgeen tot uitdrukking kan komen in de tijd die men voor een bepaalde beslissing beschikbaar heeft of in de snelheid waarmee men informatie verwerkt in de vorm van het aantal mogelijkheden dat men kan onderscheiden. Dit kan een rol spelen bij de koopbeslissing van consumenten. Neem bijvoorbeeld de aankoop van een stereotoren. Hiermee is meestal niet één prijs geassocieerd, maar een prijs voor elk onderdeel (tuner, versterker, etc.). Als deze prijzen nu zijn gebaseerd op de kwaliteit van de onderdelen, dan kan de consument uit de prijs iets afleiden over de onderliggende kwaliteit. De hoogte van de cognitieve capaciteiten van de klant bepaalt zijn aankoopbeslissingsregel. Een consument van niveau 1 gaat slechts tot koop over wanneer de prijs van de gehele stereotoren beneden een bepaald geldbedrag ligt, terwijl een consument van niveau 2 niet tot koop overgaat wanneer de prijs binnen een bepaald interval ligt. (Een interval heeft twee grenzen, hetgeen een consument van niveau 2 net kan behappen.) Deze laatste beslissingsregel voorkomt dat bij koop van een stereotoren te veel wordt betaald voor een bepaald onderdeel.

Een ondernemer die met klanten met verschillende cognitieve capaciteiten te maken heeft kan 
de complexiteit en samenstelling van de prijslijst zodanig kiezen dat extra wordt verdiend aan de consumenten met de laagste cognitieve capaciteiten. De complexiteit van de prijslijst kan door ondernemingen derhalve strategisch worden aangewend.

Een vraag met betrekking tot consumenten van niveau 1 is hoe zij met hun beperkte cognitieve capaciteiten in staat zijn om de meest attractieve regel te kiezen uit alle mogelijke simpele aankoopbeslissingsregels. (Dezelfde vraag kan natuurlijk worden gesteld voor consumenten van niveau 2.) Een mogelijk antwoord op deze vraag wordt in de volgende paragraaf geformuleerd.

\section{Inductieve beperkte rationaliteit}

Gedrag wordt in veel simpele situaties goed benaderd door de voorspellingen van een theorie die is gebaseerd op beslissers die volledig rationeel zijn. In meer gecompliceerde situaties zijn mensen niet meer in staat om analytische methoden toe te passen. Beslissingen vinden inductief plaats en worden nog slechts gebaseerd op fragmentarische informatie. Voor onderdelen van een probleem kan weliswaar een logische, deductieve aanpak worden gevolgd, maar vaak zal een inductieve aanpak nodig zijn voor het gehele probleem. Met ontbrekende informatie wordt in complexe, vage problemen op inductieve wijze omgegaan door het vormen van hypothesen, het trekken van analogieën en het gebruik van heuristische vuistregels op basis van feedback van de omgeving. Er worden plausibele, eenvoudiger weergaven van het probleem geconstrueerd zodanig dat ermee kan worden omgegaan. Een bepaalde weergave blijft men als werkhypothese gebruiken zolang er succes mee wordt behaald, zelfs wanneer men niet begrijpt waarom het werkt. Leren in de vorm van feedback en het aanpassen van vuistregels op basis van natuurlijke selectie dienen zich hiermee aan als belangrijke ingrediënten in de theorievorming omtrent het gedrag in complexe omgevingen.

De inductieve analyse van problemen met een hoge complexiteit in vergelijking tot de cognitieve capaciteiten van beslissers vindt voornamelijk plaats met behulp van computersimulaties. De evolutie van een systeem met vele beslissers (cellen) wordt nagegaan door ze zodanig te programmeren dat ze parallel en van elkaar leren. Elke cel kan een aantal toestanden aannemen.
Neem voor de eenvoud aan dat dit er slechts twee zijn, bijvoorbeeld 1 of 0 , aan of uit, waar of onwaar of levend of dood. Elke cel bepaalt zijn volgende toestand met behulp van een eenvoudige transitieregel die alleen gebruik maakt van informatie uit de lokale omgeving. In het platte vlak hebben twee lokale omgevingen veel aandacht gekregen. Een Von Neuman omgeving bestaat uit de cellen die horizontaal en verticaal langs de gegeven cel liggen, terwijl de Moore omgeving ook nog de aangrenzende diagonale cellen bevat. Deze twee omgevingen zijn weergegeven in figuur 1. Het aantal mogelijke transitieregels dat op een cel en zijn lokale omgeving kan worden toegepast is meestal erg groot. De meeste regels leiden niet tot interessante resultaten als gevolg van de interactie tussen de cellen, maar er zijn enkele regels die tot verrassende geaggregeerde resultaten leiden. Het onderzoek is gericht op het vinden van dergelijke regels die daarenboven ook nog eenvoudig zijn. Een voorbeeld van een dergelijke regel in Moore omgevingen is dat een levende cel ook in de volgende periode leeft wanneer twee of drie van de acht cellen in de omgeving ook leven. In alle andere gevallen sterft de cel omdat het te druk is ( 4 of meer levende buren) of omdat het te eenzaam is ( 0 of 1 levende buren). Een dode cel komt tot leven in de volgende periode dan en slechts dan wanneer er drie van de acht cellen in de omgeving leven.

Figuar l:

(a) Von Neuman omgeving: (b) Moore omgeving

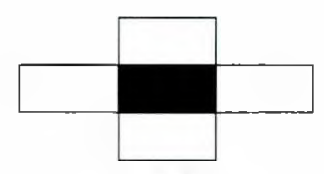

(a)

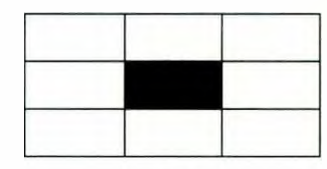

(b)
Het onderzoek richt zich op het in kaart brengen van de onderliggende mechanismen (transitieregels) die ervoor zorgen dat de interactie tussen cellen, met een willekeurige verdeling van toestanden als startpunt, na verloop van tijd leiden tot complexe patronen. De resulterende patronen zijn in principe niet precies te voorspellen ('undecidability theorem'). Het startpunt van een evolutionair proces is vaak in belangrijke mate bepalend voor het uiteindelijke resultaat. Dit brengt met zich mee dat slechts probabilistische uitspraken kunnen worden geformulerd. Ex post is het weliswaar mogelijk om het evolutionaire (histori- 
sche) proces te traceren, matr ex ante is dat niet mogelijk. Het historische proces in de vorm van de factor toeval krijgt daarmee naast het proces van natuurlijke selectie een belangrijke rol in de verklaring van vele verschijnselen.

Onderzoek met behulp van de computer biedt echter uitkomst. Een computerprogramma kan worden geschreven zodanig dat het resultaat van clke overgang op het scherm verschijnt. Na enkele transities verschijnen al interessante patronen. In liguur 2 is een patroon weergegeven, genaamd glider, dat na enkele overgangen zijn oorspronkelijke vorm weer alanneemı. (De lezer kan zelf nagaan dat de glider op basis van de bovenstaande leven-sterven transitieregel na vier stappen zijn oorspronkelijke vorm weer heeft aangenomen en zich naar het zuid-oosten heeft verplaatst.) De literatuur (Sigmund. 1993) staal bol van de exotische namen (Beacon, Eater, Snake. Acorm, Canoe, Beehive, r-Pentomino) voor relatief eenvoudige patronen. Interessant is nu om te zien dal uit de interactie van dergelijke eenvoudige patronen bijzonder complexe patronen kunnen ontstaan. Dit kan leiden tot simulatieresultaten die verrassend veel gelijkenis vertonen met hel complexe gedrag van levende wezens of organisaties.

Figutur 2: Glider

\begin{tabular}{|l|l|l|l|l|}
\hline & & & & \\
\hline & & & & \\
\hline & & & & \\
\hline & \multicolumn{4}{|c|}{} \\
\hline & & & & \\
\hline
\end{tabular}

Succesvolle regels zijn in staat om zichzelf ain te passen, dat wil zeggen te leren van de lokale omgeving. om zich zodoende te handhaven in het proces van natuurlijke selectie. Zij vertonen een subtiele balans tussen exploratie en exploitatie van de lokale omgeving via eenvoudige transitieregels. Een resultaat ten aanzien van de hiermee gepaard galinde globale dynamiek van het leergedrag op basis van lokale transitieregels is het schema theorema (Holland. 1975). Het houdt in dat compacte clusters/patronen die goed presteren in evolutionaire omgevingen exponentieel in aantal toenemen in de populatie van patronen. Evolutie verloopt snel gezien het enorme alantal mogelijkheden dat er bestaat omdat het eerder gericht lijkt te zijn op het vinden van goede bouwstenen/modules/patronen die dienst kunnen doen in het samenstellen van een gecompliceerde structuur, dan op het direct construeren van een gecompliceerde structuur. Daarnaast heefi deze hiërarchische structuur van modules ook invloed op de mogelijkheden van het systeem om te evolueren, leren en aanpassen.

Ain complexe systemen lijken dus 'bottom-up' mechanismen ten grondslag te liggen van veel eenvoudiger systemen. In computersimulaties ontstaat voor het oog van de observator op basis van lokale interacties orde in het gehele systeem. Binnen het kader van de geïnstrueerde regels vindt op relatief korte termijn een verrassend complexe zell-organisatie van de vele bestanddelen plaats. Dit blijkt vooral het geval te zijn wanneer een systeem zich bevindt op hel grensvlak tussen orde en chaos.

De hier uiteengezelte benadering is conceptueel niet volledig nieuw, maar er is een antal grote verschillen met bijvoorbeeld de benadering van Newell en Simon (1992) in de jaren zestig. Hun methode behelst een stap-voor-stap zoekprocedure in problemen met bijzonder veel mogelijkheden, waarbij aan elke stap een heuristische zoekregel wordt opgelegd. Deze opgelegde heuristische zoekregels vindt men in de modeme computersimulat ies niet meer terug. omdat een bepaalde regel wordt gebruikt totdat (op basis van (rial and error) een betere regel zich aandient. Daarnaast is er geen sprake meer van een stapvoor-stap zoekprocedure, malar van het parallel exploreren van de immense verzameling mogelijkheden door de afzonderlijke beslissers.

Een ander aspect van het parallel evolueren en verwerken van informatie is dat er geen sprake meer is van een reductionistische benadering. Problemen worden niet meer opgesplitst in kleine deelproblemen, warvoor analytische oplossingen kumnen worden gevonden. Men geloolt nog wel dat er bepalalde universele regels (wetten) zijn die aan gedrag ten grondslag liggen, maar dat houdt niet in dat volstaan kan worden met het bestuderen van geïsoleerde problemen. Alles hangt met elkaar samen, waardoor het belangrijk wordt om de verbindingen lussen de verscheidene elementen (en derhalve een hoger aggregatieniveaul) aan onderzock te onderwerpen. Het blijkt uit computersimulaties dat relatief simpele mechanismen een verklaring kunnen vormen voor complex geaggregeerd gedrag. Biologisch leven en hel functioneren van ondernemingen ligt niet besloten in de onderdelen. maar in de organisatie van de onderdelen. 
De bovenstaande benadering heeft in vele gebieden toepassing gevonden, zoals in het werk van de celbioloog Kauffman (1993), het onderzoek naar de groei van planten door de bioloog Lindenmayer (Prusinkiewicz en Lindemayer. 1990), de computerkunde (Holland en Miller, 1991), de internationale handel (Krugman, 1994), economische geschiedenis (North. 1994) en de macro-economie (Sargent, 1994). In de volgende twee paragrafen wordt stilgestaan bij een vroege economische bijdrage ten aanzien van segregatie en een recente bijdrage op het gebied van financiële markten.

\section{I Segregatie}

De eerste economische bijdrage is geformuleerd door Schelling (1971). Hij heeft de evolutie in de bevolkingssamenstelling van woonwijken onderzocht met computersimulaties. Dit rassenintegratie-experiment toont aan dat segregatie zich al voordoet met de eenvoudige transitieregel dat je alleen dan niet verhuist naar een andere woning wanneer het percentage buren in je Moore omgeving dat van dezelfde bevolkingsgroep (ras) is boven een bepaald niveau uitkomt.

\subsection{Financiële markten}

Het vertrekpunt in het overgrote deel van de macro-economische en financiële theorievorming is vanaf de jaren zeventig de veronderstelling van rationele verwachtingen geweest. Dit uitgangspunt is op allerlei gebieden succesvol geweest, maar er zijn toch ook een aantal empirische observaties die hier moeilijk mee zijn te rijmen. Een voorbeeld is dat mensen vaak aan zeldzame gebeurtenissen te weinig gewicht toekennen.

Lettau (1993) onderbouwt dit empirische gegeven in een beleggingsmodel met inductief, beperkt rationele beslissers. Agenten beslissen over het percentage riskante beleggingen in hun portfolio, waarbij zij meer (minder) gaan beleggen in riskante fondsen wanneer er de laatste tijd sprake is geweest van positieve (negatieve) opbrengsten. Deze transitieregel leidt ertoe dat fondsen met tijdelijke negatieve opbrengsten worden onderschat wanneer aantrekkelijke beleggingsmogelijkheden prominent aanwezig zijn. Beleggingen vertonen daarmee een systematische bias in de vorm van te riskante portefeuillesamenstellingen. Een implicatie op marktniveau is dat koersontwikkelingen gedurende lange tijd een stijgende lijn vertonen. afgewisseld met korte perioden met forse koersdalingen.

\section{Beslissingen in organisaties}

In deze paragraaf wordt een aantal observaties met betrekking tot strategische besluitvormingsprocessen in de praktijk gepresenteerd. Zij zijn ontleend aan March (1988) en allerminst volledig. Daarnaast zal een contrast worden geschetst tussen deze observaties uit de praktijk en de standaard economische theorie. Sommige observaties worden gerelateerd aan enkele recente bijdragen in de economische literatuur, terwijl anderen slechts worden genoemd. Zij dienen echter alle een tweeledig doel. Enerzijds vormen deze feiten en verschijnselen een uitdaging voor de formulering van een theorie op basis van beperkte rationaliteit die ze onderbouwt en verbindt. Anderzijds kunnen zij een indicatie vormen over de aard van eenvoudige regels die aan complex gedrag ten gondslag kunnen liggen.

Tabel 2 vat gedrag ten aanzien van drie dimensies in besluitvormingsprocessen samen. In de praktijk wordt vaak weinig rekening gehouden met de gevolgen die in de verre toekomst spelen, zoals buitensporige gehoorzaamheid aan gezag en uitstel van initiatie en beëindiging van projecten.

Tabel 2: Tendenties in leergedrag

\begin{tabular}{|c|c|c|}
\hline Besluitvon & Teveel & Te weinig \\
\hline Tijd & $\begin{array}{l}\text { Nabije } \\
\text { toekomst }\end{array}$ & $\begin{array}{l}\text { Verre } \\
\text { toekomst }\end{array}$ \\
\hline Afstand & Klein & Groot \\
\hline Resultaat & Succes & Mislukking \\
\hline
\end{tabular}

Huidige opbrengsten en kosten lijken vaak meer in het oog te springen dan die in de toekomst (Akerlof, 1991). Dit is in strijd met de standaard economische gedragsveronderstelling van volledig rationele, met de toekomst rekening houdende, nutsmaximaliserende individuen.

De besluitvormingsdimensie afstand kan zowel betrekking hebben op het aantal kilometers als het verschil in belangstelling of achtergrond. Het 
Tabel 3: Besluitvorming in economische theorie

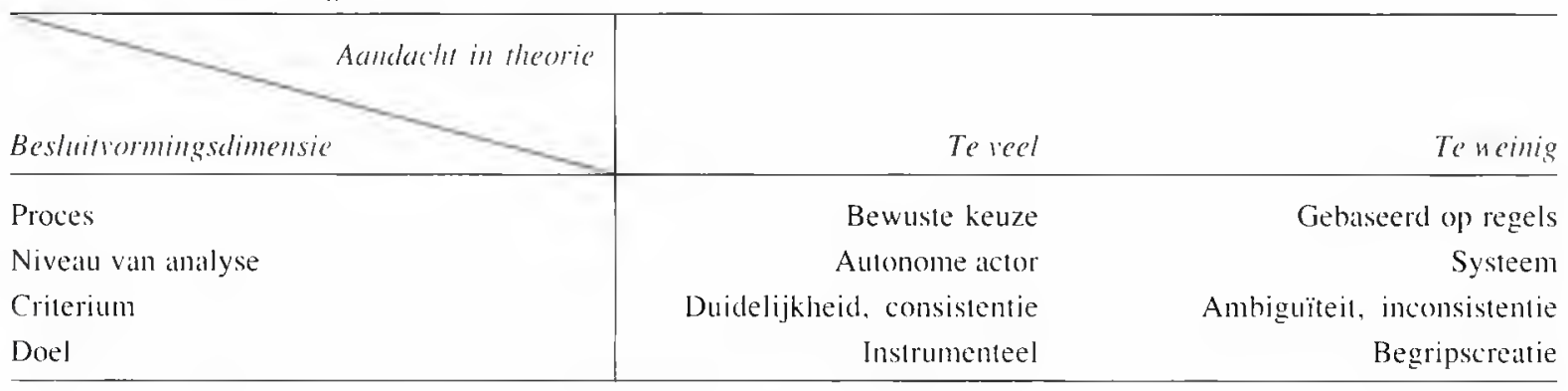

blijkt dat in leerprocessen te veel gewicht wordt toegekend aan lokale gebeurtenissen die zich sowieso al vaak voordoen in de belevingswereld van de betrokken persoon. Ontwikkelingen in Duitsland en de Verenigde Staten hebben meer invloed op besluitvorming in Nederland dan de ontwikkelingen in China. Een econoom zal meer belang hechten aan de economische dan de juridische aspecten van een probleem. Uitzonderlijke gebeurtenissen worden zelf's genegeerd, hetgeen tot uitdrukking komt in het gezegde "wat de boer niet kent dat eet hij niet'. Het blijkı bijvoorbeeld dat mensen zich niet verzekeren tegen overstromingsgevaar, ondanks dat de premie veel lager ligt dan de verwachte opbrengst ( $\mathrm{Hci}-$ ner. 1983). Dil staat op gespannen voet met de verwachte nutstheorie. Arthur (1991) heeft deze eerste twee dimensies van gedrag in besluitvorming succesvol kunnen simuleren op basis van de concepten van de vorige paragraaf.

Leerprocessen lijken ook te veel oog te hebben voor succes. In de wetenschappelijke wereld zijn empirische resultaten met significante effecten van nieuwe variabelen minder moeilijk te publiceren dan niet-significante effecten van dezelfde variabelen. In veel organisaties wordt succes beloond met promotics, terwijl dit het gevolg kan zijn geweest van te riskante beslissingen. De kans op mislukkingen wordt daardoor onderschat. Tversky en Kahneman (1992) tonen aan dat naast winst en verlies ook de grootte van de kans op succes en mislukking een rol speelt in gedrag: risico-mijdend gedrag voor winst (verlies) met een grote (kleine) kans en risico-zoekend gedrag voor winst (verlies) met een kleine (grote) kans. Deze observaties staan ook op gespannen voet met de verwachte nutstheorie en zijn door hen axiomatisch onderbouwd in de 'cumulative prospect theory'. Een verklaring voor de data vanuit een perspectief van beperkte rationaliteit is ondergetekende niet bekend. mair de gebruikte axioma's zouden een startpunt kunnen vormen in een inductief beperkt rationele analyse.

Tabel 3 geeft contrasten aan tussen enkele dimensies van besluilvormingsprocessen in de economische theorie en de dagelijkse praktijk. Het meest prominente contrast wordt gevormd door de visic op de aard van het hesluitvormingsproces. Expliciete keuzen op basis van logisch redeneren liggen volgens economen ten grondslag aan gedrag. In de praktijk lijkı het resultaat van besluitvormingsprocessen daarentegen nogal eens te zijn gebaseerd op regels. Een voorbeeld hiervan is dat mensen zich bij het bepalen van hun beslissing nogal eens volledig laten leiden door de beslissing van een ander (Simon, 1993). Een verklaring voor het ontstaan en de selectie van regels is in de vorige paragraaf aan de orde geweest.

In de meeste theorieën omtrent strategische besluitvorming staal de beslisser als autonome actor centraal. Het systeem waarin de beslisser met anderen interacteert krijgt weinig aandacht. waardoor het conflict tussen individuen in besluitvormingsprocessen onderbelicht blijft. Dit is de latste jaren overigens wel enigszins veranderd door het gebruik van zowel de speltheorie als het ecologische perspectief in de evolutionaire benadering.

Duidelijkheid en consistentie worden vaak te veel benadrukt in normalieve analyses van besluitvormingsprocessen. Ambiguïteit en inconsistentie lijken echter aan de orde van de dag te zijn. Het is niet duidelijk waarom dit zonder meer onwenselijk is wanneer op de een of andere manier een balans gevonden dient te worden tussen exploratie en exploitatie in complexe ongevingen. Evolutie trekt zich namelijk niets aan van het goed of slecht geformuleerd zijn van problemen.

Het instrumentele karakter van besluitvormingsprocessen staat centraal in de economische 
theorievorming. De rol van deze processen is in deze optiek het bijdragen tot het vaststellen van de gewenste beslissing. Interpretatieve benaderingen zien de uiteindelijke beslissing slechts als een bijprodukt van besluitvormingsprocessen. Het creëren van begrip en rechtvaardiging van je eigen handelen en het bepalen van je rol in je naaste omgeving vormen de belangrijkste functies van het besluitvormingsproces.

\section{Conclusie}

$\mathrm{Er}$ is in dit artikel stilgestaan bij verschillen tussen de standaard neo-klassieke economie en enkele recente ontwikkelingen. De standaard neoklassieke economie is voornamelijk gericht op problemen met afnemende schaalopbrengsten, volledige rationaliteit en statisch evenwicht. Daarnaast is de afgelopen twintig jaar veel aandacht besteed aan het analyseren van situaties met asymmetrische informatie waarin prestatieprikkels een prominente rol spelen. Principaalagent analyses en transactiekosten economie zijn hiervan voorbeelden en behoren ondertussen tot de standaardkennis van de moderne econoom (Hendrikse, 1993). Door het succes van deze werkwijze zijn problemen zonder afnemende schaalopbrengsten, volledige rationaliteit of statisch evenwicht onderbelicht gebleven. De notie van statisch evenwicht is niet geschikt voor evolutie-, patroon formatie- en procesproblemen. Aspecten als toeval, geschiedenis en aanpassingsvermogen gaan in dergelijke omstandigheden een belangrijke rol spelen.

Een opvallende overeenstemming in verschillende stromen van recent onderzoek is dat ook twee andere aspecten in het centrum van de belangstelling staan: de systeemeffecten van het gedrag van de afzonderlijke componenten en beperkte rationaliteit. Interessante problemen met verrassende systeemeffecten worden gekarakteriseerd door toenemende schaalopbrengsten of positieve feedback. In de economische wetenschap worden deze situaties geanalyseerd met de notie van complementariteit (Milgrom en Roberts, 1990), terwijl in de zelf-organisatie literatuur de gevolgen van co-evolutie met computersimulaties worden nagegaan. Daarnaasl is er vanuit deze twee onderzoeksgebieden tegenwoordig veel aandacht voor beperkte rationaliteit. Door de aandacht voor deze twee aspecten is er nu volop belangstelling voor de multipliciteit van evenwichten. de rol van toeval en de dynamiek van leren en toeval.

Enkele recente operationaliseringen van beperkte rationaliteit hebben centraal gestaan in dit artikel. Toepassingen hebben duidelijk gemaakt dat de 'as if' verdediging en het gebruik van volledige rationaliteit zowel positief als normatief problematisch is wanneer beslissingen hiervan systematisch afwijken. Het expliciet incorporeren van beperkte rationaliteit leidt in omgevingen met hoge complexiteit in vergelijking tot de cognitieve capaciteiten van beslissers tot zowel betere voorspellingen als betere adviezen. Op de implicaties voor het formuleren van beleid zal nu kort worden ingegaan.

Drie verschillende niveaus voor het formuleren van beleid kunnen worden onderscheiden. Kostenbaten analyse vormt het eerste niveau. De waarde van deze methode is dat het de gebruiker dwingt om de implicaties van de verschillende alternatieven na te gaan. Problemen zijn echter nogal eens vaag en onduidelijk, waardoor allerlei subjectieve overwegingen een rol gaan spelen bij het vaststellen van de hoogte van de kosten en de baten. De institutionele-politieke analyse richt zich op het systeem waarin het beleid wordt gesitueerd en brengt de verschillende partijen in kaart. Het beleid dat op dit tweede niveau tot stand komt (alsook het politieke systeem zelf) is een uitvloeisel van de interactie tussen al deze partijen. Ten slotte is er het derde niveau van analyse. Interacties tussen de verschillende partijen staan ook hier centraal, maar zij hoeven niet noodzakelijk tot de beste uitkomst voor het gehele systeem te leiden. Twee visies op de wereld zijn op dit niveau te onderkennen. Hel neo-klassieke denken in termen van evenwicht wordt gekenmerkt door een dualiteit tussen de mens en zijn omgeving. Optimaliteit van het beleid voor de mens is de leidraad voor het keuzeproces. In de complexiteit-visie is er geen sprake van een dualiteit tussen de mens en zijn omgeving, omdat alles met alles samenhangt en de gevolgen van beleid op voorhand niet eens volledig zijn na te gaan. Accommodatie en co-adaptatie voor het systeem als geheel (mens en omgeving) staan centraal, waardoor het geen zin heeft om in termen van optimaliteit te spreken. Relevante criteria voor beleid zijn in deze optiek de levensvatbaarheid en werkbaarheid van de verschillende alternatieven. 


\section{I T E R A T U U R}

Akerlof, G.A., (1991), Procrastination and Obedience, American Economic Review, 81(2), 1-19.

Arthur, W.B., (1991), Designing Economic Agents that Act Like Human Agents: A Behavioral Approach to Bounded Rationality, American Economic Review, 81(2), 353-359.

Cohen, M.D., J.M. March en J.P. Olsen, (1972), A Garbage Can Model of Organizational Choice, Administrative Science Quarterly, 17(1), 1-25

Debreu, G., (1959), The Theory of Value, Wiley.

Fershtman, C. and E. Kalai, (1993), Complexity Considerations and Market Behavior, Rand Journal of Economics, 24(2), 224-235

Friedman, M., (1953), Essays in Positive Economics, University of Chicago Press.

Hayek, F., (1945), The Use of Knowledge in Society, American Economic Review, 35, 519-530.

Heiner, R.A., (1983), The Origin of Predictable Behavior, American Economic Review, 73, 560-595.

Hendrikse, G.W.J., (1993), Coördineren en Motiveren, Academic Service.

Holland, J.H., (1975), Adaptation in Natural and Artificial Systems, University of Michigan Press.

Holland, J.H. en J.H. Miller, (1991), Artificial Adaptive Agents in Economic Theory, American Economic Review, 81(2), 365-370.

Kalai, E., (1990), Bounded Rationality and Strategic Complexity in Repeated Games, in T. Ichiishi, A. Neyman en Y. Tauman (eds.), Game Theory and Applications, Academic Press.

Kauffman, S.A., (1993), The Origins of Order, Oxford University Press.

Krugman, P., (1994), Complex Landscapes in Economic Geography, American Economic Review, 84(2), 412-416
Lettau, M., (1993), Risk-Taking Bias in a Financial Market with Adaptive Agents, Princeton University.

March, J.G., (1988), Decisions and Organizations, Basil Blackwell.

Milgrom, P. en J. Roberts, (1990), Rationalizability, Learning, and Equilibrium in Games with Strategic Complementarities, Econometrica, 58(6), 1255-1277.

Newell, A. en H.A. Simon, (1972), Human Problem Solving, Prentice Hall.

North, D.C., (1994), Economic Performance Through Time, American Economic Review, 84(3), 359-368.

Prusinkiewicz, P. en A. Lindenmayer, (1990), The Algorithmic Beauty of Plants, Springer.

Radner, R., (1992), Hierarchy: The Economics of Managing, Journal of Economic Literature, 30(3), 1382-1415.

Rubinstein, A., (1993), On Price Recognition and Computational Complexity in a Monopolistic Model, Journal of Political Economy, 101(3), 473-484.

Sah, R.K. en J.E. Stiglitz, (1986), The Architecture of Economic Systems: Hierarchies and Polyarchies, American Economic Review, 76(4), 716-727.

Sargent, T.J., (1994), Bounded Rationality in Macroeconomics, Oxford University Press.

Schelling, T., (1971), Dynamic Modes of Segregation, Journal of Mathematical Sociology, 1, 143-186.

Sigmund, K., (1993), Games of Life, Oxford University Press. Simon, H.A., (1961), Administrative Behavior, Mac Millan. Simon, H.A., (1993), Altruism and Economics, American Economic Review, 83(2), 156-161.

Simon, H.A. en C.P. Bonini, (1958), The Size Distribution of Business Firms, American Economic Review, 48, 607-617.

Tversky, A. en D. Kahneman, (1992), Advances in Prospect Theory: Cumulative Representation of Uncertainty, Journal of Risk and Uncertainty, 5, 297-323.

Williamson, O.E., (1979), Transaction-Cost Economics: The Governance of Contractual Relations, Journal of Law and Economics, 22, 233-261. 